\title{
Farm level correlation analysis of maize supply and market participation in Kaduna State, Nigeria
}

\author{
J. R. Mani ${ }^{1 *}$, Z. Abdulsalam ${ }^{2}$ and M. A. Damisa ${ }^{2}$ \\ ${ }^{1}$ National Agricultural Extension Research and Liaison Services, Ahmadu Bello University, Zaria, Nigeria. \\ ${ }^{2}$ Department of Agricultural Economics, Faculty of Agriculture, Ahmadu Bello University, Zaria, Nigeria. \\ *Corresponding author. Email: jrmani2001@yahoo.com; Tel: +234 8035968359.
}

Copyright (@ 2021 Mani et al. This article remains permanently open access under the terms of the Creative Commons Attribution License 4.0, which permits unrestricted use, distribution, and reproduction in any medium, provided the original work is properly cited.

Received 29th June, 2021; Accepted 19th July, 2021

\begin{abstract}
Maize supply is limited by the structural and institutional constraints that have persisted despite market reforms in the State. The resultant effect is that smallholder subsistence farmers remain mostly outside the mainstream exchange economy, unable to take advantage of the exchange economy. Using data collected from 600 randomly selected maize farmers, descriptive statistics and the multiple regression model, the paper examined the correlation of maize supply and market participation in Kaduna State. Results of the descriptive statistics show that the average age, level of education, number of household members participating in maize production of the farmers were 44 years, 7 years and 9 , respectively. The outcome of the multiple regression analysis established that maize supply is directly and significantly responsive to quantity of maize output sold (proxy for market participation) (0.956) and technical efficiency of farmers $(739.29)$ at $(p<0.01)$ of probability. Other significant variables were age $(61.653)$, level of formal education $(114.074)$ and years of farming experience, which were significant at different levels $(p<0.05, p<0.01$ and $p<0.01$, respectively). In conclusion, maize supply is directly and significantly responsive to market participation and technical efficiency of farmers. Maize farmers can increase commercialization through contract farming and produce buying centres. There is also the need for continuous government support to the agricultural sector.
\end{abstract}

Keywords: Correlation, maize, market participation, output, technical efficiency.

\section{INTRODUCTION}

More than 300 million people in sub-saharan Africa (SSA) depend on maize as source of food and livelihood (International Institute for Tropical Agriculture, IITA, 2019). It is the most widely grown staple food crop in SSA, occupying more than 39 million hectares each year (Food and Agricultural Organization of the United Nations Statistical Database, FAOSTAT, 2020) covering nearly $24 \%$ of the estimated 200 million hectares cultivated land. In Nigeria, maize was introduced in the 16th century, it is the most frequently produced and consumed staple food (Cadoni and Angelucci, 2013). The country is the 10th largest producer of maize in the world, and the largest producer in Africa (United States Agency for International Development, USAID and IITA, 2012; IITA, 2019). While
Kaduna State is by far the leading producer of maize in Nigeria, with an annual production in 2006 of about 907,000 tonnes (Delaporte et al., 2015), about 795,590 Metric tonnes in 2016 and about 927.16 Metric tonnes in 2019 (National Agricultural Extension and Research Liaison Services, NAERLS, and Federal Ministry of Agriculture and Rural Development, FMARD, 2017; 2020), producing about $22 \%$ of the country's maize. The ministry of Agriculture of the State saddled with the responsibility of providing policy direction for the government, has over the years devised blue-prints, policies and strategies for bridging the gap between demand and supply affecting maize production and marketing under the Kaduna State Agricultural Development Project KADP (Kaduna State 
Government, KDSG, 2021) These policies have been based on the need to transform traditional maize and agricultural production through the adoption of modern farm technologies and provision of extension services and agricultural support for rural dwellers (Iwuchukwu and Igbokwe, 2012) with the objective of poverty alleviation and sufficiency. Transformation of traditional production involves moving from subsistence production to increasingly more market-oriented pattern. Markets allow farmers to increase their income by marketing produced surplus, purchasing technological inputs and engaging in non-farm activities.

Nkang et al. (2007) stated that the behavioural changes of producers with respect to the production, consumption and exchange decision of a certain product or set of products is due to changes in the economy. While the concept of market participation has been well-defined and translated in several ways. Two interpretations can be deduced from the work of Barrett (2007): households can participate in markets either as buyers or sellers, both seeking to maximize utility subject to the cash constraint and available non-tradable resources. Mason and Liverpool-Tasie (2016) indicated that the household is a price taker in all markets, for all commodities which it both consume and produce, optimal household production can be determined independent of leisure and consumption choices. Then, given the maximum income level derived from profit-maximizing production, family labour supply and commodity consumption decisions can be made. It follows then that the structure and access to markets is critical in shaping the behavioural supply of agricultural households in designing their livelihood strategy (Brooks et al., 2008). The assumption as stated by Taylor and Adelman (2003) is that as long as markets are perfect for all goods (including labour), households remain indifferent between consuming own produced and market-purchased goods. And by consuming all or part of its own output, which could be sold at a given market price, the household is implicitly purchasing goods from itself.

Thus, prices and technological changes are the important instruments for accelerating output supply in the agricultural sector. Therefore, positive price policy plays a significant role in stimulating production through the allocation of desired level of resources. However, according to Barrett (2007), just getting prices right does not induce broad-based, welfare enhancing supply and market participation. As such, policy planners face the challenge of formulating suitable agricultural policy by which the desired growth rate in agricultural output may be achieved, while considering the heterogeneity of farmers' decisions when it comes to taking part in market exchange while others remain self-sufficient. Maize supply is limited by the structural and institutional constraints that have persisted despite market reforms in the State (Christopher et al., 2017). The resultant effect is that smallholder subsistence farmers remain mostly outside the mainstream exchange economy, unable to take advantage of the exchange economy. There is, therefore, a pressing need for empirical understanding of the relationship between maize supply and market participation in order to enable informed policy formulation that will work appropriately towards output supply and farmers' decision to participate in markets.

\section{Hypothesis}

There is no significant relationship between maize supply and market participation among maize farmers in Kaduna State.

\section{MATERIALS AND METHODS}

Primary data were collected in 2016/2017 production season through the administration of structured questionnaires administered on selected maize farmers in Kaduna State. The State lies between latitudes $90^{\circ} \mathrm{N}$ and $12^{\circ} \mathrm{N}$ of the equator and between longitudes $6^{\circ} \mathrm{E}$ and $9^{\circ} \mathrm{E}$ of the prime meridian, occupying $7 \%$ of Nigeria's land mass (Kaduna State Government, 2016). Eight (8) Local Government Areas (LGAs), 2 from each agricultural zones of Kaduna State were selected, based on the number of maize farmers in the LGA using Kaduna State Agricultural Development Project (KADP) village listings, 2016. The respondents were proportionally and randomly selected from a registered maize farmers' cooperative society in each of the LGAs resulting in a total of 600 (Table 1) respondents. Ten percent $(10 \%)$ of sample frame from each cooperative was randomly selected.

\section{Analytical technique (multiple regression model}

Multiple regression model was used in predicting the value of a variable based on the value of two or more other variables. The model was used to determine the relationship between maize supply and market participation. Separately, technical efficiency of the farmers was also estimated. The main model is as presented in Equation 1:

$Z_{i}=\alpha+\beta_{1 i} X_{i}+\beta_{2} \omega_{i}+\beta_{3} \omega_{e}+E_{1 i}$

Where $Z_{i}=$ output supply (measured as quantity of maize in $\mathrm{kg}$ ), $\alpha=$ constant term, $\beta_{1}, \beta_{2}$ and $\beta_{3}=$ are parameters to be estimated, $X_{i}=$ vector of exogenous variables (hypothesized to be correlated with both maize supply and market participation), $\omega_{i}=$ the value of sales in market participation, $\omega_{e}=$ technical efficiency of farmers $E_{i}=$ error

Where, $X_{i}$ is given as; $X_{1}=$ age, $X_{2}=\operatorname{sex}(1-$ male, 0 - 
Table 1. Selected LGAs and sample size of farmers.

\begin{tabular}{llcc}
\hline KADP zone & LGAs & Sample frame & Sample size \\
\hline \multirow{2}{*}{ Samaru } & Jaba & 390 & 39 \\
& Kagarko & 600 & 60 \\
Lere & lgabi & 1090 & 109 \\
& Lere & 860 & 86 \\
Birnin-gwary & Birnin-gwari & 650 & 65 \\
& Chikun & 940 & 94 \\
Maigana & Soba & 730 & 73 \\
Total & Giwa & 740 & 74 \\
\hline
\end{tabular}

female), $X_{3}=$ formal education (years of schooling), $X_{4}=$ number of household partaking in maize production, $X_{5}=$ extension advice (number of visits), $X_{6}=$ farm size (ha), $X_{7}=$ membership of farmer association (1=yes, $0=$ otherwise), $X_{8}=$ farming experience (years of experience in maize production), $X_{9}=$ distance to spot market $(\mathrm{km}), X_{10}=$ access to market information (1=yes, $0=$ otherwise), $X_{11}=$ access to credit( $\left.\$\right), \omega_{i}=$ quantity of maize output sold $(\mathrm{kg}), \omega_{e}=$ technical efficiency of farmers

The specified profit function for estimating the technical efficiency of the farmers is written as;

$$
\ln \Pi^{*}=\alpha_{0}+\sum \alpha_{i} \ln p_{i}^{*}+\alpha_{k} \ln z_{\mathrm{k}}+v_{i}-u_{i}
$$

Where $\Pi=$ profit (revenue less variable costs) maize $(\#) / \mathrm{kg}, \mathrm{p}_{\mathrm{i}}^{*}=$ set of exogenous variables of the ith maize farmer, $\alpha_{i}=$ parameters to be estimated; $v_{i}=$ error term, $u_{i}=$ technical inefficiency of the ith maize farmer.

\section{RESULTS AND DISCUSSION}

There is an interdependence of production and consumption decision in an agricultural household, because the deciding entity in both cases is the producer. The agricultural household chooses the allocation of labour and other inputs to produce goods and services as a producer; while choosing the allocation of income from farm profits and labour sales to the consumption of commodities as a consumer. That is, given the maximum income level derived from profit-maximizing production, family labour supply and commodity consumption decisions can be made. It is in this manner that this section presents the basic characteristics of the maize farmers and market participants in Kaduna State.

Descriptive statistics of the variables employed in the study are presented in Table 2. The average age, level of education, number of household members participating in maize production of the farmers were 44 years, 7 years and 9 respectively. Age is assumed to be a function of labour productivity. Tauer (2017) indicated that productivity increases with age, peaks at mid-life and then decreases by age ceteris paribus, and young people are more willing to take risks and adopt new methods of production than old people. The mean schooling years of 7 years reveals that level of education among maize farmers is low. This does not however fall below the United Nations Development Programme mean education index of 5 years for Nigeria (United Nations Development Programme, UNDP, 2018). This suggests that maize farming in Kaduna State is mainly carried out by farmers who are semi-literates. This is comparable with the views of Girei et al. (2018), they suggested that the majority of the maize farmers in Toto Local Government Area of Nasarawa State had one form of formal educational or the other.

The average number of household members participating in maize production is 9 . That is, households with more members partaking in maize farming activities would probably have abundant labour available for farming. The availability of more than one working member in a household would increase easy access to cheap family labour to intensify food production and reduce cost of labour. As such, the number of the household members that can participate in farming activities affects the amount and availability of farm labour, poverty status and often times, level of commercialization. Abu and Soom (2016) indicated that the number of persons in the household is the source of family labour that can work on the farm for increased food productivity.

Amount of credit accessed by the farmers has an average of $\mathrm{N} 18,558.34$ with a very high standard deviation

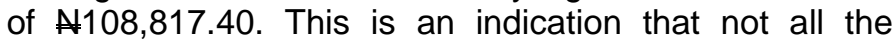
farmers had access to credit for maize production in the study area. The mean years of maize farming experience is 20 years; this is suggesting that the selected maize farmers in Kaduna State are middle aged. The mean number of extension visits per year is 17 with minimum and maximum of 0 and 20, respectively. This shows that majority of the respondents had little or no access to extension services in the study area. Notably, extension service is critical to the improvement of maize farming and 
Table 2. Descriptive statistics of variables.

\begin{tabular}{lcccc}
\hline Demographic characteristics & Mean & Min & Max & Std.Dev \\
\hline Age (years) & 44 & 19 & 65 & 10.19 \\
Years of experience & 20.31 & 0 & 40 & 10.65 \\
Household members in maize production & 9.13 & 1 & 21 & 6.61 \\
Level of education (years) & 6.86 & 0 & 19 & 5.12 \\
Cooperative association (years) & 2 & 0 & 20 & 10.65 \\
Distance to physical spot market (km) & 16.24 & 0 & 20 & 61.28 \\
Amount of credit (A) & 18558.34 & 0 & 1600000 & 108817.40 \\
Extension visits (number) & 17 & 0 & 20 & 61.28 \\
Farm size (ha) & 2.72 & 0.5 & 20 & \\
Quantity of maize produced (kg) & 2317.07 & 200 & 1203100 & 17.34 \\
Quantity of maize sold (kg) & 2296.15 & 0 & 70000 & 49493.90 \\
\hline
\end{tabular}

efficiency among the farmers. The maximum years spent in an association by a farmer is about 20 years, this shows that maize farming cooperative have established for quite some time. Although the association is active in the study area, it is clearly underdeveloped.

The mean farm size in the study area is about 2.72 ha. The maximum farm size for a smallholder farmer in Nigeria is about 1.7 ha, while the maximum national farm size is about 14.7 ha (FAO, 2021). Although the mean farm size owned by the respondents is slightly above 1.7 ha, they are still classified as smallholder farmers by FAO's classification of smallholder farmers. In their review of smallholder farming in Nigeria, Mgbenka et al. (2016) reported that by international standards, a farm that is less than 10 hectares is classified as small scale. The average yield of $2,317.07 \mathrm{~kg} / \mathrm{ha}$ have high standard deviations of 12,637.60. This implies that maize farmers operated at different levels of input use, which affected their output and consequently yield levels. NAERLS and FMARD (2020) reported that on the average, maize farmers in Kaduna State produce about $2,580 \mathrm{~kg} / \mathrm{ha}$ of maize. The average quantity of maize sold is about $2,296 \mathrm{~kg}$, while there are farmers who did not sell maize at all. These farmers are referred to as autarkic and they remain self-sufficient. The high standard deviation of quantity of maize sold is an indication of significant variation among farmers in terms of maize marketing.

\section{Relationship between maize supply and market participation}

Estimated result for establishing a relationship between maize supply and market participation are presented in Table 3. The result of the analysis reveals that the estimated $R^{2}(0.4597)$ shows that $45.97 \%$ of the variation in the dependent variable (maize supply) has been predicted by the independent variables. Although the Rsquared is low, there is an indication that the data have significant trend. The trend indicates that the predictor variable still provides information about the response even though data points fall a little further from the regression line. Maize supply is directly and significantly responsive to quantity of maize output sold (proxy for market participation) with a coefficient of 0.956 at $1 \%$ level of probability (Table 3). A one percent increase in quantity of maize output sold will lead to a proportionate increase in quantity of maize supplied by $0.956 \%$. This result is in line with expectation since farmers who have higher production will have more surplus to sell in the market. This report is similar to the findings of Reyes et al. (2012) who reported that farmers with greater production have more surpluses they could sell. Therefore, increase yield or surplus production results in larger marketed surplus of maize and serve as an incentive for a household to participate in market.

On the other hand, a $1 \%$ increase in technical efficiency of farmers will lead to a more than proportionate increase in maize supply by $739.29 \%$. This means that improved productivity of maize farmers can increase supply and consequently drive commercialization. Rios et al. (2009) and Tariku et al. (2018) reported that sales index has a significant positive correlation with productivity (technical efficiency) in Vietnam and Guatemala, and Ethiopia. Consequently, Heltberg and Tarp (2001) indicated that maize yields in Mozambique have the greatest marginal impact on market participation, for both poor and non-poor households. As such, generating a marketable surplus, which in turn depends on productivity can influence market participation.

With respect to other significant variables, the regression coefficient for age was positive (61.653) and significantly different from zero at $5 \%$. This finding shows that age has a significant influence on maize output supply, that is older farmers are more likely to supply maize. All things being equal, the skills of a farmer should increase with age which in turn should increase yield and subsequently supply. However, the expected effect of age on supply could be 
Table 3. Relationship between maize supply and market participation.

\begin{tabular}{llccc}
\hline Variables & Parameters & Reg. coeff. & Standard error & t-value \\
\hline Constant & $\beta_{0}$ & $-3837.1^{*}$ & 2209.26 & -1.74 \\
Age (years) & $\beta_{1}$ & $61.65^{\star *}$ & 28.75 & 2.14 \\
Sex (dummy) & $\beta_{2}$ & -684.34 & 1008.69 & -0.68 \\
Formal education (years) & $\beta_{3}$ & $114.07^{* * *}$ & 45.19 & 2.52 \\
Household members in maize production (number) & $\beta_{4}$ & -28.19 & 36.62 & -0.77 \\
Extension advice (number) & $\beta_{5}$ & -5.08 & 4.28 & -1.18 \\
Farm size (ha) & $\beta_{6}$ & 0.36 & 5.45 & 0.07 \\
Farmer association (dummy) & $\beta_{7}$ & 1140.17 & 1193.51 & 0.96 \\
Farming experience (years) & $\beta_{8}$ & $50.11^{*}$ & 27.77 & 1.80 \\
Distance to market (km) & $\beta_{9}$ & 38.13 & 26.68 & 1.43 \\
Access to market information (dummy) & $\beta_{10}$ & -1216.41 & 1476.76 & -0.82 \\
Access to credit (\#) & $\beta_{11}$ & 0.001 & 0.002 & 0.7 \\
Maize output sold (kg) & $\beta_{12}$ & $0.96^{* * *}$ & 0.05 & 18.52 \\
Technical efficiency & $\beta_{13}$ & $739.29^{* * *}$ & 169.51 & 4.36 \\
$\mathrm{R}^{2}$ & 0.4597 & & & \\
$F$ & 38.36 & & & \\
$\bar{R}^{2}$ & 0.4477 & & & \\
\hline
\end{tabular}

${ }^{* * *}$ significant at $1 \%,{ }^{* *}$ significant at $5 \%$, *significant at $10 \%$.

positive or negative, depending on whether the farmer is in his/her active or inactive age. It can therefore be said that, age has great potential for increasing agricultural productivity and supply, and for reducing poverty in the study area and vice versa. Alawode et al. (2020) opined that, farmers already leaving their active age will not be as productive as youths. The level of formal education revealed a positive coefficient (114.074) and statistically significant at $1 \%$. That is, higher level of education is associated with higher level of maize supply. Literacy is an indication of human capital and theory has postulated more educated farmers are more likely to adopt new innovations and good agricultural practices there by increasing their output supply. Additionally, higher level of education could mean better access to information network which is likely to increase agricultural supply and subsequently market participation. However, this does not agree with the findings of Issa et al. (2016), in their study of analysis of socio-economic factors influencing farmers' adoption of improved maize production practices in Ikara Local Government Area of Kaduna State, Nigeria.

Years of farming experience also indicated a significantly ( $1 \%$ level of significance) positive relationship with maize supply. In other words, a year increase in farming experience will increase maize supply by 50.1 percent. Oladimeji et al. (2013) indicated that experience may be positive or negative, and that up to a certain number of years, experience would have a positive effect. There is therefore an indication that such features of adoption of new technology and hence ability to produce surpluses for the market can be influenced by experience.
Also, farmers with more years of farming experience are expected to have greater market contacts and trust that would allow them to trade at higher costs.

The parameter estimate for sex was not statistically significant and also negative. Although the negative sign of the coefficient shows that female maize farmers are more likely to supply maize, the non-significance of the variable indicates that sex of the farmer does not significantly influence maize supply. This is an indication that maize supply in Kaduna State is not a totally male or female dominated aspect of agricultural production. This finding strengthens the debate that equal access to productive assets for both male and female can increase supply and market participation and consequently reduced poverty.

\section{Test of hypothesis}

The result of the regression analysis (Table 3) shows that there is a significant relationship between maize supply and market participation. Therefore, the hypothesis of no significant relationship between maize supply and market participation can be rejected.

\section{Conclusion and recommendations}

The farm level correlation analysis of maize supply and market participation in Kaduna State, Nigeria was investigated. The result of the regression analysis revealed that 
maize supply is directly and significantly responsive to quantity of maize output sold and technical efficiency of farmers. To improve on maize market participation (commercialization), private-public partnership by organizations dealing with agricultural inputs, developmental agencies as well as farmer-based associations, cooperatives, and societies can increase maize commercialization through contract farming and produce buying centres. Furthermore, involving youths through capacity building by the State Government in maize production process will help to increase the productivity of farmers.

\section{CONFLICT OF INTEREST}

Authors declare that they have no conflict of interest.

\section{REFERENCES}

Abu, G. A., \& Soom, A. (2016). Analysis of factors affecting food security in rural and urban farming households of Benue State, Nigeria. International Journal of Food and Agricultural Economics, 4(1), 55-68.

Alawode, O. O., Kabiru, B. A., \& Akanbi, O. A. (2020). Land use intensity, crop diversification and productivity of farmers in Akinyele Local Government Area of Oyo State, Nigeria. International Journal of Innovative Environmental Studies Research, 8(3), 20-32

Barrett, C. B. (2007). Smallholder market participation: Concepts and evidence from Eastern and Southern Africa. Food Policy, 33(2008), 299-317.

Brooks, J., George, D., \& Taylor, E. (2008). Modelling agricultural trade and policy impacts in less developed countries. OECD Food, Agriculture and Fisheries Working Papers, No. 11, OECD publishing.

Cadoni, P., \& Angelucci, F. (2013). Analysis of incentives and disincentives for maize in Nigeria. Technical notes series, Monitoring African Food and Agricultural Policy (MAFAP), FAO, Rome. Retrieved from http://www.fao.org/mafap.

Christopher, S. I., Otohinoyi, S., \& Shanum, L. D. (2017). Impacts of commercial agricultural development project (CADP) on farmers' empowerment in Kaduna State (2010-2016). International Journal of Development and Management Review, 12(1), 92-113.

Delaporte, A., Jordan, C., \& Singh, S. (2015). Nigeria's strategic grain reserves department school feeding linkages. Home Grown School Feeding (HGSF) working paper (No. 14).

Food and Agriculture Organization of the United Nations (FAO) (2020). FAOSTAT statistical database. [Rome]: FAO

Food and Agriculture Organization of the United Nations (FAO) (2021). Food and Agriculture Organization of the United Nations, Rome, Italy. Retrieved from http://www.fao.org/familyfarming/data-sources/dataportrait/countrydetails/en/?cnt=NGA

Girei, A. A., Saingbe, N. D., Ohen, S. B., \& Umar, K. O. (2018). Economics of small-scale maize production in Toto local government area, Nasarawa state, Nigeria. Agrosearch, 18(1), 90-104.
Heltberg, R., \& Tarp, F. (2001). Agricultural supply response and poverty in Mozambique. Food Policy, 27(2), 103-124.

International Institute for Tropical Agriculture (IITA) (2019). Maize. Retrieved from https://www.iita.org/cropsnew/maize/.

International Institute for Tropical Agriculture (IITA) (2012). Growing in Nigeria. Commercial crop production guide series. Information and communication support for agricultural growth in Nigeria. United States Agency for International Development (USAID). $\quad$ Pp. 1-8. Retrieved from https://www.fas.usda.gov/data/nigeria-grain-and-feed-updat.

Issa, F. O., Kagbu, J. H., \& Abdulkadir, S. A. F. (2016). Analysis of socio-economic factors influencing farmers' adoption of improved maize production practices in Ikara Local Government Area of Kaduna State, Nigeria. Agrosearch, 2(16), 15-24.

Iwuchukwu, J. C., \& Igbokwe, E. M. (2012). Lessons from agricultural policies and programmes in Nigeria. Journal of Law, Policy and Globalization, 5, 11-21.

Kaduna State Government (KDSG) (2016). About Kaduna State. Retrieved from https://kdsg.gov.ng/about-kaduna/.

Kaduna State Government (KDSG) (2021). Ministry of Agriculture-Kaduna State Government-The Ministry. Retrieved from https://agric.kdsg.gov.ng/the-ministry/.

Kaduna State Agricultural Development Project (KADP) (2016). Farm family village listings of Kaduna State.

Mason, N. M., \& Liverpool-Tasi, S. (2016). An Introduction to Agricultural Household Models. Agricultural Households as Producers and Consumers: Set-Up and Insights from a Basic Ag Household. IAPRI-MSU Technical Training, Indaba Agricultural Policy Research Institute, Lusaka, Zambia. Retrieved from https://docplayer.net/136557978-lapri-msutechnical-training-an-introduction-to-agricultural-householdmodels.html

Mgbenka, R. N., Mbah, E. N., \& Ezeano, C. I. (2016). A review of smallholder farming in Nigeria: Need for transformation. International Journal of Agricultural Extension and Rural Development Studies, 3(2), 43-54.

National Agricultural Extension and Research Liaison Services (NAERLS) and Federal Ministry of Agriculture and Rural Development (FMARD) (2017). 2017 Wet Season Agricultural Performance in Nigeria. NAERLS Press, Zaria.

National Agricultural Extension and Research Liaison Services (NAERLS) and Federal Ministry of Agriculture and Rural Development (FMARD) (2020). 2020 Wet Season Agricultural Performance in Nigeria. NAERLS Press, Zaria.

Nkang, N. M., Ndifan, H. N., \& Edet, E. O. (2007). Maize supply response to changes in real prices in Nigeria. A vector error correction approach. Agricultural Journal, 2(3), 419-425.

Oladimeji, Y. U., Abdulsalam, Z, \& Damisa, M. A. (2013). Socioeconomic characteristics and returns to rural artisanal fishery households in Asa and Patigi LGAs of Kwara State, Nigeria. International Journal of Science and Nature, 4(3), 445-455.

Reyes, B., Donovan, C., \& Kelly, V. (2012). Baseline survey report: Raising the incomes of smallholder farmers in the Central Highlands of Angola: A model project for improving agricultural value chains in post-conflict nations. Retrieved from http://citeseerx.ist.psu.edu/viewdoc/download?doi=10.1 $1.481 .9998 \&$ rep $=$ rep $1 \&$ type $=$ pdf.

Rios, A. R., Shively, G. E., \& Masters, W. A. (2009). Farm productivity and household market participation: evidence from LSMS data. Paper presented at the International Association of Agricultural Economis t Conference in Beijing, China, 16-22 
August 2009.

Tariku, A. D., Tegegne, B., \& Zemedu, L. (2018). Analysis of market decisions and intensity of market participation of smallholder wheat farmers in Adola Rede District of Oromia Regional State, Ethiopia. International Journal of Research Studies in Agricultural Sciences, 4(8), 1-11.

Tauer, L. W. (2017). Farmer productivity by age over eight US census years. In: International Farm Management Association Conference (pp. 2-7).
Taylor, J. E., \& Adelman, I. (2003). Agricultural household models: genesis, evolution and extensions. Review of Economics of the Household., 1(1), 1-43.

United Nations Development Programme (UNDP) (2018).

Human developments report. Retrieved from http://hdr.undp.org/en/2018-update. 